\title{
Kosovar Emigration: Causes, Losses and Benefits
}

\author{
Besim Gollopeni
}

\author{
University of Mitrovica "Isa Boletini", Prishtina, Republic of Kosovo \\ e-mail: besim.gollopeni@gmail.com
}

\begin{abstract}
Migrations of population have been an integral part of the society throughout history. Countries with low levels of economic development like Kosovo are emigration countries, while immigration countries are those countries that have developed economies and social and political stability. Kosovar emigration until the beginning of the second half of the 20th century was individual migration (male workforce) headed to major industrial centres of the former Yugoslavia, whereas after the 1970s, it spread to European countries. Unfavourable economic and political situation is one of the main causes of Kosovar emigration. According to the population census (2011), approximately $30 \%$ of the general population of Kosovo live abroad. Remittances from emigration play an important role in the development of Kosovo. However, there are also negative aspects of emigration such as the loss of young population, the loss of skilled population, gender and age disbalance in the country of origin etc.

By analyzing the statistical data and various studies, using analytical, historical, comparative and demographic methods, this paper aims to investigate the time periods of emigration, socio-demographic features of Kosovar emigration, emigration according to the municipalities of Kosovo, destinations of emigration, motives, losses and benefits of emigration.
\end{abstract}

Key words: migrations, host society, motives, losses, benefits.

\section{Introduction}

The migrations of the population are component part of social evolution. Migration from one place to another one, constitute one of the global problems the world is facing. Migration from undeveloped countries such as the Middle East, Asia, Africa and the Western Balkan countries towards developed countries (Europe and USA), took an important place. They become part of the daily agenda of global policy making, as they took a deserved place and in scientific aspect. In this context, Kosovar society has no exception. Taking into account the historical aspect, there are various sources about the Kosovar emigrations since the time periods of Albanians emigration (arvanitas) in Greece, (arberesh) in Italy, Bulgaria, Romania, Russia, Dalmatia, Srem and later on to other countries. 
Before the World War II, and nearly two decades later (up to 70s), many Kosovo Albanians emigrated to large industrial centres of the region such as: Serbia, Macedonia, Slovenia, Croatia and Bosnia and Herzegovina, in order to find job and ensure better living conditions, since on that time Kosovo was economically undeveloped. According to the data of the Association of Employment in 1963, from Kosovo have been working in other territories of the former State 11,058 employees, out of them 3827 in Macedonia or 35\%, from this year in this former republic the number of employees began to decrease while growing up in Serbia, Slovenia and Croatia. In 1966 this number decreased to 4039 employees, with nearly 70\% working in Serbia, with the tendency of evident decrease after this year (Islami, 2012). Kosovar emigrants until the 1960s were labourer, unskilled and were engaged in hard works such as black metallurgy, construction, mining, mines, etc. The status of Kosovo Albanian emigrants remains the same situation for decades to come. Around 1980s the Kosovar guest workers were mainly young men without families. They were coming mainly from rural and poor areas. They was working on unskilled work places and often living in barracks with foreign workers (Dahinden, 2005).

During the first years of the existence of the Socialist Federal Republic of Yugoslavia (SFRY) (1945-64), as well as other socialist countries in the Balkans, Eastern Europe and the Soviet Union - SFRY was closed regarding the emigration abroad. However, this was not the case for many Kosovo Albanians. Many Kosovo Albanians migrated massively to Turkey, especially during the beginning of $1960 \mathrm{~s}$ at the top of the repressive policies of ruthless chief of Serbian security Aleksandar Rankovic (Haxhikadrija, 2009). The next wave of migration was related to the political decision of the Yugoslav Federation to open its borders for emigrants, which was accompanied by launching of (national) economic liberal reforms (1965). Statistics show that since the 1960s there is a tradition of the Kosovo Albanians population to emigrate. The habit and various tendencies of emigration trends can be explained by several sociopolitical factors, (Blaku, 1996; Blumi, 2003). The Yugoslav government had made repeated attempts to initiate talks with Turkey and Albania about the admission of some of Yugoslavia's Muslim population mainly Turks and Albanians and showed readiness to conclude such arrangements and to cover the costs and compensations. A plan for resettling 200,000 Muslims from Yugoslavia to Turkey was drafted in Ankara in July, 1938. (Bjelajac, 2008) The beneficiaries of this agreement were to be some 40,000 families of "Yugoslav Muslims". According to the draft the resettlement programme was to be completed within six years (1939-44) (Bjelajac, 2008). This plan was re-initiated in the 1950s and was implemented by the ruthless minister of interior Aleksandar Rankovic. This group of migrants was destined to become permanent migrants from the onset as most of them sold their properties in Kosovo before settling permanently to Turkey (Gashi et al., 2012).

The next phase occurred in 1998 during the outbreak of the war in Kosovo, which led to a phase of mass emigration to Europe and other countries. Between March and June 1999, an estimated 850,000 refugees fled into neighbouring Albania, Macedonia and Montenegro, threatening wider regional instability (Haxhikadrija, 2009). Some 200,000 people were internally displaced or homeless inside Kosovo itself. While the majority of refugees remained in Albania, Macedonia, Montenegro and 
approximately 90,000 of them - by total (Miall et al., 2010) moved to over 25 countries around the world through legal arrangements (Gashi, et al. 2012).

And finally, the final stage of migration was after 2000. In 2014 / 15, according to the statistics of KAS about 100000 Kosovo citizens is considered that have emigrated. This research, through the use and analysis of official statistics and compering different studies, contributes on the presentation of migration according to the time periods, socio-demographic characteristics of the Kosovar emigration, and destinations of Kosovar emigration. After analyzing the migration based on evidences and studies, this research gives response to the questions as: What are the main causes of Kosovar emigration? What are the losses from emigration? And what are the benefits of Kosovar emigration for the Kosovo state and society?

\section{Kosovar emigration during $1950-2015$}

Kosovar emigration took place throughout the XX century. In the first half of the XX century, Kosovar emigration was component part of the agenda of the Yugoslav and Turkish state. At this time, the migration of the Kosovar population in Turkey was permanently - no return. In most cases, emigrants sold their ownerships and immigrated to Turkey as part of the agreement between Yugoslav state and Turkey (see above). During 50s and 60s, the Kosovar population has migrated to the region countries, to ensure a better family welfare, as these countries were rich and needed work force. After 60s, the migrations of Kosovar population were extended toward European Union countries, United States and less in other faraway countries. The data of census for the period after 1960, show that the emigration of Kosovo has an important place in society. (See the chart).

Graph 1.

External migration of Kosovo society in the second period of XX and beginning of XXI century

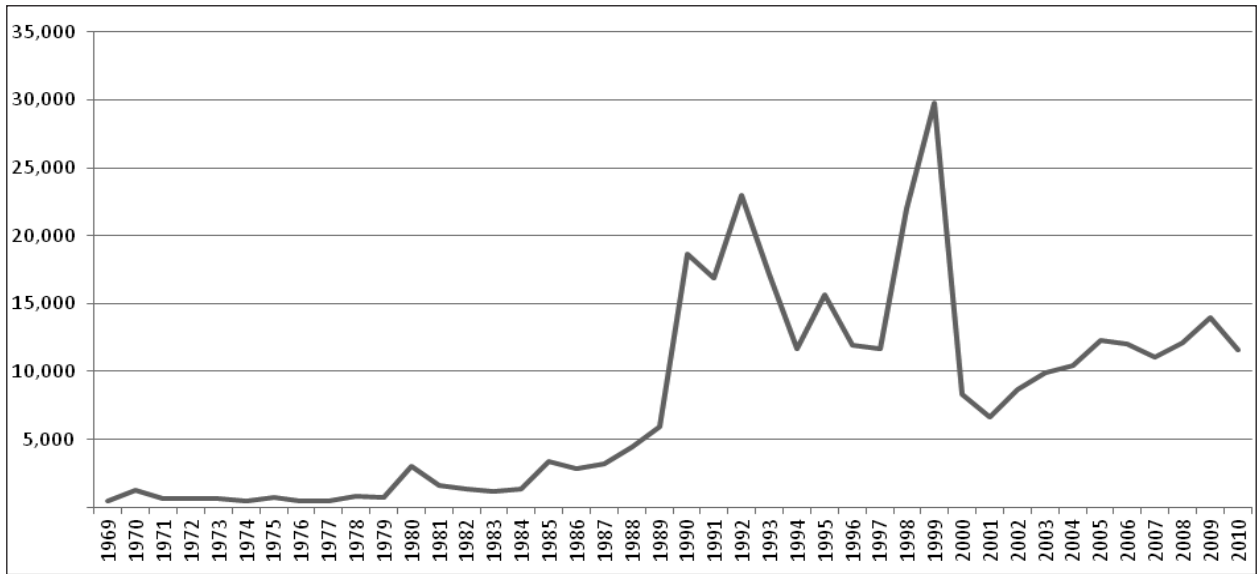

Source: KAS, Kosovar migration, 2014, pg. 24. 
According to the presented data, the huge number of Kosovar emigrated during the 90s and especially in 1999. During the 90s, Kosovar emigrations were increased as a result of deterioration of political and socio-economic situation. The 90s will be remembered for a long time in the collective Kosovar memory and beyond as Kosovo emigration years. Many young people in this period, living in anxiety and fear because of the political circumstances and the difficult economic situation, choosing emigration as the only alternative for a better life and welfare. In the early 90s, under the violent measures by Serbian occupiers, most of the Kosovo Albanian workers were fired, pupils and students were expelled from school banks, hospitals were closed, and the prominent Kosovar intellectuals were arrested and prosecuted, thus paralyzing the social life of the Kosovar society. In 90s the only University in Kosovo (University of Pristina) was closed, the size of family was subject of limitations and ethnic Kosovars were "non grata" (undesirable) persons regarding the jobs in public institutions. Human Rights Watch noted that persecution "forced emigration of some 350,000 Kosovo Albanians over the next seven years". Members of the nationalist elite among Kosovar students were increasingly prosecuted and forced to leave Kosovo (Malcolm, 1999). On the other hand, Kosovar youth was persecuted and arrested to be sending to the military service of Serbia, therefore, to send to the wars in Croatia and Bosnia and Herzegovina. The Kosovar Albanian youths, to escape participation in the military service of the Serbian state and their representation in the wars in the region were forced to seek asylum in European countries and elsewhere. In 1999, the state of Serbia committed all Serbian police and army, to evict (move) the society of Kosovo abroad the border, to Albania, with the aim of ethnic cleansing and occupation of Kosovo. After the liberation of Kosovo, many Kosovar citizens expelled from Kosovo, were returned back to start a new life, however, there were refugee who did not return to Kosovo. By August 1999, 850,000 Albanian refugees returned to Kosovo and around 100,000 ethnic Serbs from Kosovo, approximately half of the ethnic Serbian population in Kosovo, fled to Serbia (Elsie, 2011) and north of Kosovo.

According to the census of population, households and housing in Kosovo (2011), from Kosovo have emigrated $380.826^{1}$ persons (overall migration balance was -15.9). In relation to the resident population in Kosovo, according to the population census, $21.4 \%$ of the population was living outside of Kosovo ${ }^{2}$. However,

1 Clarification; ASK has made the prognosis for the population that has migrated and that from Kosovo since 1969-2011. As representative value KAS in the necessary calculations has taken the average value of the natural increase, the number 153978 of children born abroad. Thus, the number of emigrated Kosovar population and with the Kosovar origin (1969-2011) is estimated to be around 703978 inhabitants.

2 I quote KAS: According to official data collected from the questionnaire S1, the number of people (Those born in Kosovo only) WHO HAD emigrated from Kosovo Were 380,826 people. In relation to the resident population in Kosovo, according to these data, $21.4 \%$ of the population living abroad. For international migration, the Following tests are made based on the number of persons registered WHO during the month of April 2011. 
this data even though official, are not true and this findings are supported among others by numerous critics of professionals of this field that took the population census (2011), leaving out of the census, a large number of non resident population (Diaspora) ${ }^{3}$ in Kosovo. Such a non-compliance with data on the number of emigrants acknowledges itself the Kosovo Agency of Statistics. I quote; "the Kosovo Agency of Statistics (KAS) is aware that the number of emigrants is greater, given that some of them during the population census did not have relatives to provide information on the number of members of the households that previously emigrated from Kosovo" (KAS, 2014).

Whereas, the latest wave of emigration from Kosovo, was after 2000 and spatially in late of 2014 and early 2015, where, according to estimations of the respective institutions, for around 6 months, approximately 100,000 Kosovar citizens left Kosovo, emigrating to European countries and wider. In the latest wave of emigration, beside others social and economic factors, the major influence was the political situation (political stoppage), six months after the political central elections (2014) in Kosovo, the local institutions were not established (government and parliament), thus causing a loss of hope for the citizens of this country, that in a near future there may be social and economic progress.

\section{Emigration by Kosovo municipalities}

Kosovo consists totally of 38 municipalities and they are distributed throughout Kosovo. All municipalities of Kosovo are involved in emigration, and mostly suburban and rural municipalities. The undeveloped countries are mainly emigrant countries, while developed countries are immigrant countries. Considering the economic development aspect, Kosovo throughout XX century but even then, was considered as one of the most underdeveloped countries in the region and Europe, therefore, necessarily means that it is an emigration country. Regarding the degree of migration by Kosovo municipalities, where there are differences of migration, some municipalities have higher rates of migration and some other lower. See the graph;

3 Clarification; in the population census (2011), the population living and working abroad is left outside of the registration process. During the registration a quite simply questionnaire was designed, with few questions and the questionnaire was not mandatory to be implemented on the field, thus leaving the possibility to the will and desire of the registrants the field. The population Census, denied the right for the registration of children born abroad, as was the fact that others fulfilled the data for persons or families living abroad, and in this cases there were no relatives who would give these data, so they remained without being registered, thus can be a very large number of migrants. 
Graph 2.

The number of emigrant population by municipalities in Kosovo (2011)

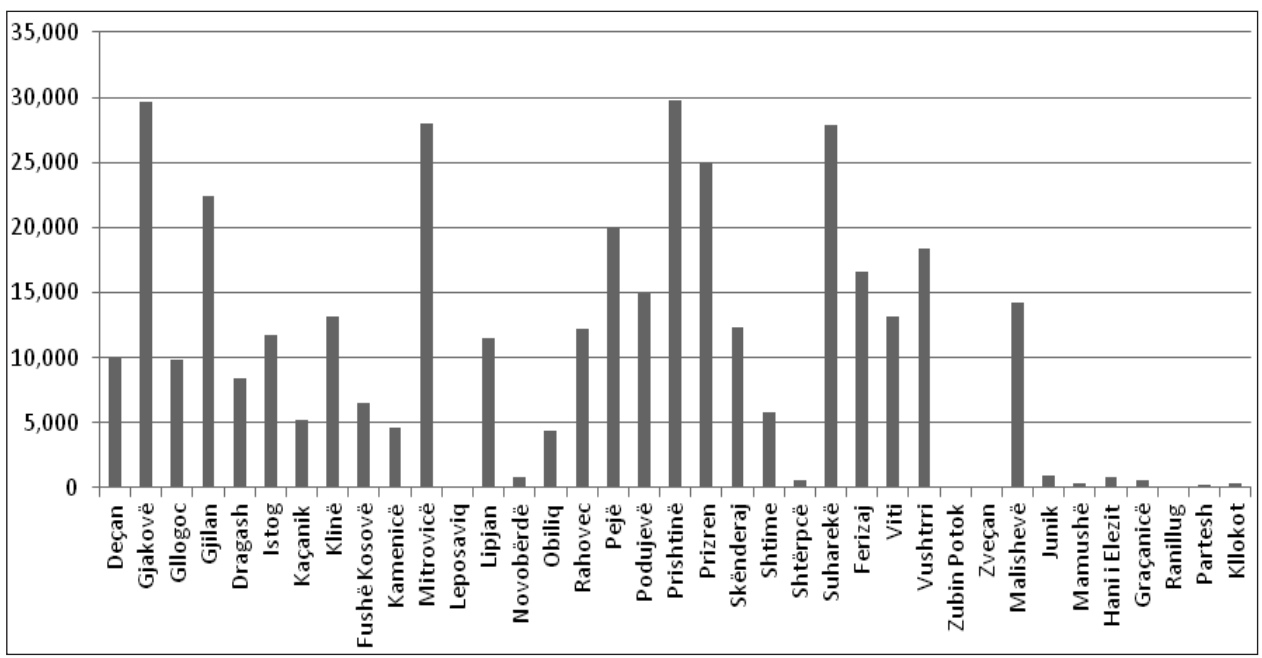

Source: KAS, 2014.

Data shown above by the census (2011) indicate that the municipalities with higher rates of migration (in absolute numbers) are; Prishtina, Gjakova, Mitrovica and Suhareka. Three first municipalities are part of the largest municipalities in Kosovo, therefore, it is normal to have the largest absolute number of migration on the one hand, and on the other hand, these municipalities have been among most industrialized municipalities of Kosovo up to 1990, in which after 1991, the factories were closed and workers were dismissed of their jobs. As mentioned above, also a large part of the population, in particular the workforce was forced to seek work abroad, in Europe and elsewhere. Meanwhile, the Municipality of Suhareka is a middle sized of the municipalities of Kosovo for numerical population and average economic growth, but, one of the municipalities with high levels of emigration. This municipality, except that it had the same fate with other municipalities, regarding the closure of factories and dismissal of workers from Serbian authorities, there is a tradition in migration, and this perhaps has led, especially during 90s and later to migrate a large number of youths, to the countries where they had their relatives. Another fact that makes the Municipality of Suhareka to have such a high degree of migration (above the average of Kosovo) is the fact that the municipality has managed to register and collate data on migration (Gollopeni, 2015).

Based on the analysis of data on emigrants in relation to 1,000 inhabitants in Kosovo during 2011 were $218.8^{4}$ emigrants per 1,000 inhabitants. See table;

\footnotetext{
${ }^{4}$ Clarification: the number of emigrants per 1000 inhabitants in Kosovo might be much higher ore approximately same with Suhareka municipality, as if there were registered all emigrants, as was mentioned above.
} 
Table 1.

The number of emigrants per 1,000 resident inhabitants in Kosovo

\begin{tabular}{|c|c|c|c|c|c|}
\hline $\begin{array}{c}\text { Number of emigrants } \\
\text { Total population }\end{array}$ & $X=$ & K & $\begin{array}{r}380,826 \\
1,739,825\end{array}$ & $X 1.000=$ & 218.8 \\
\hline
\end{tabular}

In 2011, the degree of emigration in Kosovo was 218.8 emigrants per 1.000 inhabitants.

International migration balance for 2011 was -142 (or -142 migrants in 1000 inhabitants) (KAS, 2014). Although this number of emigrants is very high, it does not reflect the real situation of emigrants per 1,000 inhabitants, knowing the fact that a considerable number of emigrants remained outside the population census and as such the population census (2011) had its own deficiencies. The most real situation about the number of emigrants in Kosovo, we have in the municipality of Suhareka because this municipality for the first time in Kosovo in 2009 had established the Directorate for Diaspora, which directorate later on had made the update of data on emigrants for each settlement and family separately. Also, during the population census in Kosovo (2011), this municipality included in the census process the Diaspora, therefore, the data for Diaspora from this municipality are more realistic than in other municipalities of the Kosovo. This fact is also admitted by KAS, appreciating very high the work done in the municipality of Suhareka during the census. This made the municipality of Suhareka to have the highest rate of migration than the average of Kosovo. See table;

Table 2.

The number of emigrants in the Municipality of Suhareka per 1,000 resident inhabitants

$\begin{array}{cccccc}\frac{\text { Number of emigrants }}{\text { Total population }} & X= & K & \underline{28.418} & 81.000= & 322.5\end{array}$

In 2011, the degree of emigration in Suhareka was 322.5 emigrants per 1.000 inhabitants.

The municipality with the highest negative balance of international migration is Suhareka - 40.2, (KAS, 2014). The analyzed data also show that in the municipality of Suhareka are 322.5 emigrants per 1,000 inhabitants, spread in different countries of the World. According to the analyzed data, it appears that the municipality of Suhareka is one the municipalities of Kosovo with high level of emigration and with emigration degree higher than the average of Kosovo. On the other hand, there are the municipalities with smaller degree of migration, which are; the Municipality of Ranilluga, Partesh and Mamusha. Characteristic of these municipalities with small-scale migration is the fact that these municipalities as such are established by the decentralization process in Kosovo after 2000, and are municipalities with small number of inhabitants, and at the same time are populated by minority communities (Serbs, Turks, etc.) so the migration of the population of minority communities (excluding the Serbian community), compared to the majority community, has been in a lower scale. 


\section{Destination of Kosovar emigrations}

Destination or selection of the immigrant country is characteristic of all types of migration. Although, depending on the social, economic and political situation in which the society is, migration aims to move to more developed countries, which guarantee a better and prosperous living. After the Second World War, main destination of Kosovar emigrants were countries in the region, whereas later on (after 60s), Western Europe countries ${ }^{5}$. The better part of the society has immigrated to European countries 96\% (1971) while, the rest part to other countries. Within European countries most Kosovar workers where immigrated in the Federal Republic of Germany (74.7\%), Austria 8.6\%, Switzerland 5.9\% and France 4.2\%. According to the census of 1981 Germany was the first country with workers immigrants from Kosovo (51.9\%), while Austria and France kept approximate the number of 1971, but it was increased the number of workers from Kosovo to Switzerland (from 5.9 in 1971 to $32.1 \%$ of all workers abroad) (Islami, 2012). This trend of migration destination of Kosovars continued for decades later. This is $17.1 \%$ of the total household population represented in the survey sample which suggests (subject to survey imitations) that the population of Kosovo would be about one sixth larger if these people not had left Kosovo, or if they all were willing to return. More than one fourth (27.0\%) of emigrants left between 2005 and 2009, and 22\% left in each of the two five-year periods before that (SOK, 2011). According to the census (2011), Germany remains one of the main destination of Kosovar emigrants (35.25\%), followed by Switzerland with (22.94\%), Italy 7.26\%, Austria 5.61\%, Sweden 5.14\%, US 3.53\%, etc. See table;

Table 3.

Emigration by states (10 leading countries of destination) expressed in percentage.

\begin{tabular}{|c|c|}
\hline Ten (10) leading countries & $\%$ \\
\hline Germany & 35.25 \\
\hline Switzerland & 22.94 \\
\hline Italy & 7.26 \\
\hline Austria & 5.61 \\
\hline Sweden & 5.14 \\
\hline USA & 3.53 \\
\hline France & 3.25 \\
\hline England & 2.79 \\
\hline Belgium & 2.07 \\
\hline Slovenia & 1.78 \\
\hline other & 10.38 \\
\hline
\end{tabular}

Source: KAS, Kosovar Migration, 2014

5 Clarification; here is excluded the displacement of Albanians in Turkey (before and after 1950). 
Countries like Germany and Switzerland are among the countries with the largest number of Kosovar immigrants since 1971 respectively 1981 up to 2011, however, both these countries have recorded an overall decrease of migrants compared to previous periods, which composed 51.9\% Germany and 32.1\% Switzerland (1981) of all workers abroad Kosovo. During the past two decades, Kosovo migrations evolved in many countries of the world such as; Italy, Sweden, USA, France, England, Belgium, Slovenia, etc., allowing the creation of Kosovar Diaspora everywhere. Unlike Kosovo where the main destination of migrations are Germany and Switzerland, main destination of the Albania migrations (World Bank, 2008) are Greece, Italy, Germany, Canada, Turkey, France, United Kingdom.

Characteristic of migration is selection of the immigration country. How it comes to the selection of immigrant country?! Any individual, group or families, before migrating, makes an analysis of the countries in which they are interested to migrate and for one reason or another, select the country that is considered most appropriate. Before migrating, each social category takes into account some indicators such as the place that offers better conditions for living, the country that recognizes immigrants and allows easier opportunities for regulating the documentation, relations with relatives in the immigrant country, easiness on employment and high income, knowledge of the host language, and other indicators. The study conducted with 497 emigrants in Kosovo (face to face), namely in the municipality of Suhareka, points out that on the selection of the immigrating country the emigrants have taken into account the better living conditions $40.2 \%$ in the immigrating country, then emigrants who migrated for family reunion $39.6 \%$, reunion with friends and relatives 6.1\%, easier documentation providing (residence and work permit) 3.4\%, closeness with the place of birth $0.2 \%$, and other reasons $10.5 \%$ (Gollopeni, B., 2015). All these of forms of migrations are an integral part of the migration of Kosovo society. While, the above-mentioned all indicators are determining the selection of the immigrating country (state), also for other migratory societies everywhere in the world, with some differences.

Until the 80s, Kosovar emigrations were of individual character (workforce). From 90s, with the deterioration of the political situation in the first place and the social and economic situation afterwards (90), Kosovar emigrants began to take their families into exile, thus, extending from the individual migrant into family one. In this form are created the preferences for immigration countries. Eg today, Kosovo municipalities are identified in emigration countries, such as: in Germany are mostly emigrants from the region of Prishtina, Mitrovica and Vushtrra, then, in Switzerland are mostly emigrants from the municipality of Gjakova, Gjilan and Suhareka, etc. So, the migration in the Kosovo context and creation of Diaspora across the World is like a chain consisting of its own links, where each link is linked to another one. So, each Kosovar citizen who has migrated before, after a period of time, has pulled away even other relatives (family, friends, etc.), thus, creating the Kosovar diasporas in the World. 


\section{Demographic and socio-economic characteristics of Kosovar emigrants}

Demographic characteristics of migrations have a special importance both for the emigrating and immigrating country. Migrations have effect on gender and age debalance, and also other social, economic, political and cultural processes of society. The emigration of Kosovar society, involves mainly the young generation of the population, the workforce. The particularity of Kosovar emigration by age groups and gender is that, until the early of 90s have migrated mostly the young people (workforce) dominated by males who look for work to ensure the existence of their families left in Kosovo. The deterioration of the political and economic situation in the 90s and particularly to the war in Kosovo (1999) has caused that many Kosovar families to emigrate during this period. Family emigration continued even after the liberation (1999) and independence of Kosovo (2008), due to the difficult economic situation and lack of perspective. Serious fragilities persist in the economy. With an unemployment rate of around $45 \%$ and youth unemployment rate of $76 \%$ (World Bank, 2008), with $15 \%$ of the population living in extreme poverty and $45 \%$ living in poverty (World Bank, 2007), conditions favor emigration for economic reasons.

In addition, Kosovo is known to have Europe's youngest population (UNDP, 2006, taken by Artjoms et al., 2008). According to the results from the Population and Housing Census of 2011 the average size of households in Kosovo is 5.9 members (SOK, 2011). Kosovo is a country with a very young population with about one third under 15 years of age; two thirds (65\%) belong to the 15-64 age group which is known as economically active or working age population. People age 65 and older represent only $7 \%$ of the household population (SOK, 2011).

The young age of the population has a higher tendency to emigrate, this conformed by the case of Kosovo emigration. Based on data for the second half of the XX and beginning of XXI century, the population that emigrated, mostly are the young age group (20-35), mainly dominated by the male gender with lower education. This is the most economically productive population and in the most vital aspect of reproduction. This is characteristic of the work force of Kosovo, where the majority workers in foreign countries is the age 20-35 (70\%). The data by the employment service show that even after the 1971 census, the composition of the work force in Kosovo is mostly young and in small percentage of women (Islami, 2012). Migration has mostly attacked the undeveloped areas of Kosovo, the rural areas. Characteristic of Kosovar migrations for the period of 1971 was the low educational qualification. Mostly the workers who migrated, have stated that "they are not employee" (70.3\%), which means that they were persons who, before going to work abroad were not employed in the public sector, or temporarily unemployment, they have not seek for work for the first time, but they were with unqualified structure, who before going abroad, were farmers of private agricultural economies. After the group who "is not an employee" comes the qualified workforce (11.5\%): these are the workers who are qualified before going abroad, mainly as craftsman, metal-processing, workers in construction, in mining, etc., meaning on the group of activities of the secondary sector, in which they were employed abroad (Islami, 2012). The representation by age and gender of emigrants remains almost the same even in 1981. The educational 
and professional composition of emigrants also remains unfavourable: $80 \%$ of the total emigrants were with primary education and about $10 \%$ with secondary education. Emigrants before emigrated also had very unfavourable professional structure (48.4\% farmers and other employees in the primary sector, $22.7 \%$ miners, workers in industry, construction, etc., 3.5\% workers in the tertiary activities and $16.6 \%$ had answered in general "workers", "employees" (Islami, 2012). The Low level of education for Kosovar emigrants continues to be also after 2000. From the total number of emigrants, 44.4\% have completed the secondary school, 26.8\% the primary school, $12.7 \%$ incomplete primary education, 5.8\% have university degree, $3.6 \%$ uneducated and 6.7\% other (Gollopeni, 2015). The lack of high qualifications of emigrants makes them carry on hard works in immigration country and also have uncomfortable life (far away from the standards of the host country) with many difficulties, especially with adaptation with the new environment (language, culture, rules, etc.). Saving money (financial means) in order to send back home, help their families, relatives and parallel institutions established by Kosovar society, make their life far away from the standards of the hosting country.

Different situation with the above mentioned periods regarding the gender report is in 2011. In 2011 the gender report of the Kosovar population that emigrated was: $56.67 \%$ male and $43.33 \%$ female. Migration in the earlier periods was characterized by male domination, that because in the past, emigration was oriented mostly on male workforce. Thus, the gender report of emigration is approximated during 20002004, while in recent years (around 2011) is the female gender which dominates in emigration: $52.94 \%$ females and $47.06 \%$ males (KAS, 2014). Impact on the increase of female representation in emigration undoubtedly has had family reunions and marriages. While, in terms of age - groups of emigrant the significant number of the population aged $0-14$ years, $16.9 \%$ indicates that they moved abroad until 2011 (family migration remains significant). The Age group 25-44 years comprised $47.2 \%$ of the emigrant population (main reproductive age in terms of fertility and workforce), while the age group 30-34 was predominant with 12.7\% (KAS, 2014).

Table 4.

Population abroad Kosovo and resident population by age groups

\begin{tabular}{|c|c|c|}
\hline \multirow{2}{*}{ Resident domicile } & \multicolumn{2}{|c|}{ Population by age groups expressed in percentage } \\
\cline { 2 - 3 } & Dependent population (0-14 and 65+) & Active population (15-64 years) \\
\hline Outside Kosovo & 19.4 & 80.6 \\
\hline Kosovo & 34.7 & 65.3 \\
\hline
\end{tabular}

Source: KAS, 2014

Characteristic of Kosovar emigrations is the dominance of the active age - workforce and expressed in percentage is higher than the same age group of the resident population in Kosovo. Also, the dependent population is lower than the one of the 
same category in the country of the origin. While the average family size ${ }^{6}$ on emigration is 4 members, lower than the one of the country of the origin (Kosovo) that is 5.9 members per family. Of those with children, the vast majority - 56\% - have 3-4 children. The average age of children who have emigrated is 11.5 years. The average age of emigrants is 28 years, which is younger than the average resident population of Kosovo (31).

Authors, who have studied the Kosovo Albanians in Switzerland (Dahinden), describe Kosovo Albanian community in Switzerland mainly as young, with only a small number of elderly and high numbers of children. The Kosovo Albanian families are generally large, with an average of 4.07 members per family. In addition, fertility rates among Kosovo Albanians is higher than the average for Western Europe (2.6 births per woman in 2000 - Wanner, 2005) tendency which confirms the size of Kosovo Albanian family in Switzerland will remain large and will therefore have a direct impact on the level of remittances to be sent home. It also confirms that Kosovar Albanians will remain among the biggest groups of the Diaspora in Switzerland in a near future. While, in terms of Serbian ethnicity emigrants; about 56 percent of emigrants are female and 44 percent male; the average age is 38 years; 68 percent are married and 81 percent have a high school education. Slightly more than three-quarters of Serb ethnicity migrants live in Serbia; 3 percent in Montenegro and 18 percent in other countries (1 percent in Germany, 1 in Switzerland and 6 does not show the country) (Riinvest, 2007). Similarities between the two groups are presented in terms of their educational background. The educational is increase after 2000. Doing emigrants to engaged in public life, employed in important sectors of social life: politics, education, health, sport clubs, large enterprises etc., and it is important that there are a considerable number of Kosovar emigrants who are successful entrepreneurs in different countries of the world.

According to the research of Riinvest Institute (2007), despite the progress recorded in the area of professional development, the construction sector is represented with the largest number of employed emigrant from Kosovo (38.8\%), followed by hotels and restaurants (13.0\%), manufacturing (12.7\%), agriculture (5.3\%), trade (5.3\%), transport and communication (5.1\%), health and education (4.7\%), public services (2.3\%), financial sector (banks, insurance companies, etc.) (2.1\%), mining (1.3\%), other (8.1\%). Regarding the level of employment according to the same study, the total number of employees $7.57 \%$ have managerial/supervisory workplace, $0.9 \%$ administrator, $82.16 \%$ employees with lower qualifications, seller $4.68 \%$ and others $4.68 \%$. Comparing the level of employment of Kosovar emigrants by sectors with prior periods, there is significant progress e.g. primary and secondary sector has emphatic decreased with the earlier periods (around 80s) but still remains an obstacle the low level of education of Kosovar emigrants. It is noteworthy that, there are a considerable number of young people (emigrants) who attend studies in prestigious

$\mathbf{6}$ This study was prepared for the 2015 Forum by the Reinvest Institute based on the research developed in Kosovo, Germany, Switzerland, Belgium, United Kingdom, Sweden, Austria and USA. 
world universities as there are academics (teaching), physicians, politicians, sportsman's, etc., who are engaged in public life of host societies, which two decades ago was only a dream for Kosovar emigrants, but now it became a reality. In general, the Kosovar emigrants everywhere around the world have demonstrated high culture, will and dedication to work, are integrated into the hosting society, creating permanent friendships and showing high success in various fields of social life.

\section{Main motives of emigration, losses and benefits}

Main motives of emigration - motives are numerous, different in time and space, specific and general and it is difficult to say that this or that is the main and only motive of migrations. In general, migrations are caused by external factors such as wars and natural disasters as well as economic reasons, for a better life, education and other factors. Generally it is likely to move from less developed countries (such is and Kosovo case) to developed countries. In order to understand the reasons or motives of Kosovar emigration in general, we analyzed through two factors, such as: Push and Pull factors.

At the beginning of the XX century, and after the Second World War, as a result of Serbian chauvinist policies for ethnic cleansing of Kosovo Albanian, pressure, persecution and systematic violence against Kosovars makes a large number of Kosovo Albanian population to be displaced in an organized manner from their lands to the state of Turkey and Albania. Except the ratification (1953) of the agreement of Yugoslavia and Turkey in 1937 for the deportation of Albanians known as "Gentlemen's Agreement", the scientific circles prepared elaborates for the deportation of Albanians, as it was the elaboration of V. Cubrilovic (1944) that was continuation of the first elaborate sequel (1937), I. Andriq (1939), S. Moleviq (1941), D. Mihajloviq (1942) etc., all these based on "Naçertanie" of Ilija Garashaninit of 1844 (Behrami, 2013). The displacement of Kosovo Albanians was well planned and organized by the Serbian state, under the pretext of agrarian reform, but the only intention was the colonization of the ethnic Albanian territories with Slavic element (Serbian, Bulgarian, Montenegrin etc.) and to balance the ethnic nationality between Albanians and other ethnic minorities and in particular the Serbian one. According to Miranda Vickers some 195,000 Kosovo Albanians left for Turkey in the years 1954-57 (Vickers, 1998).

After 60s, there were also other motives of emigration such as: migration of workforce to the countries of former Yugoslavia initially and later on also to the countries of Europe. Due to the continued growth of the labour demand (workforce) and the lack of labour offers in Kosovo a considerable number of Kosovar society were obliged to seek work abroad. During the 80s, after the deterioration of the political situation in Kosovo, began the systematic persecution of Kosovo Albanians, especially the political and academic elite but also others on the pretence of nationalist elements. This situation has pushed a large number of youths to emigrate abroad seeking for political asylum in European countries to escape imprisoning, ill-treatment and executions with political background. In the late 80s and early 90s, Kosovo Albanians prosecuted and arrested except the nationalist element, to be sent 
to the military service of the Serbian state, and then from there to the wars against different countries of the former Yugoslavia (Bosnia and Herzegovina and Croatia). So, in order to escape wars, most of the Kosovo Albanian youth and others social groups were forced to emigrate, to seek for political asylum in various countries of Europe and beyond. During the 90s the social, economic and especially the political situation was extremely deteriorated, causing the emigration of a large number of the population. In the early 90s, it prevails an emergency situation in Kosovo, where the Albanian majority population under violence left their places of work and the public life in general, coming into a situation that involuntarily to go to exile in order to ensure survival for themselves and their families left in Kosovo. The lack of public services, high levels of unemployment, difficult living conditions, persecutions and arrests, makes a large number of Kosovo Albanian populations especially the workforce to seek for asylum in various countries of Europe and beyond. The culmination of this entire extraordinary situation was reached in 99, where Kosovo Albanians population were forced through the use of police, military and paramilitary force from the Serbian invasive, to displaced from their homes to Albania and other countries. As a result of this cause inflicted to the civil population made the international community (NATO) to intervene militarily. After the military intervention of the international community in Kosovo, were evacuated the Serbian police and military forces from Kosovo, and the liberation of Kosovo (June 1999). In 1999 many citizens who were exiled (displaced) from Kosovo, returned back to their homes. Despite the widespread destruction that happened to residential buildings, businesses and infrastructure in general, the beginning of a new life was made possible with the support of the international community and savings by Kosovar emigrants. However, even after the investments made by the international community in Kosovo, the social and economic situation in the country remained fragile. The high level of unemployment and poverty has pushed many young people to migrate to developed countries.

On the other hand, we have pull factors. These factors have been intensified especially during the second half of the XX century, where a considerable number of Kosovar workforce migrated to European countries and beyond, to provide employment and better living conditions. Although until 90s the family migrations were not common but this situation changed immediately after '89 - '93 where with the deterioration of the political and economic situation in the country, many Kosovar emigrants took (emigrated) their own families. This situation changed rapidly in favour of emigration, especially after 2000, practically after the liberation of the country. Finding no perspective in Kosovo (about 45\% unemployment and 15\% in extreme poverty), many emigrants who emigrated earlier, took their families in exile, (emigrated for family reunions, weddings, etc.). Emigration also touched a considerable part of the population, especially the youth ages 20-35 who did not find the perspective in Kosovo. Among the causes that led to the emigration of Kosovars are: family reasons, 46\%, employment 35\%, war in 1998 - 99 8\%, education and training purposes 1\% and other reasons 10\% (KAS, 2014).

Losses from emigration - Emigration has mostly affected the core of society, such as family. Kosovar family during all these years of emigration has been met with 
major breaking, first mowing away from Kosovo of the males (before 2000) and later on the females, especially young people. As a result of emigration, about $30 \%$ of residential houses in Kosovo are empty (KAS, 2011), the third age of the population is increased up to 7\% (2011), many houses are inhabited with only elders (pensioner), which until the 90s, the family members were large in numbers $(7.2$ members in 1991 and 5.9 per household member in 2011, SOK through the years, taken from Gollopeni, B., 2013) and the voice of children could be heard everywhere in the yards of homes and neighborhoods. Many young people, from temporary migrants were turned into permanent migrant, emigrated unmarried, and married to foreign nationals, changing the language, culture and customs, make them to be assimilated.

The loss of emigration is multilateral, but, spiritual losses are those that cannot be compensated ever. The lack of the physical presence of parents of children and vice versa, inadequate care and feeling for each other, accompanied the Kosovar society for decades. Many emigrants due to political and socio-economic circumstances, spent years and decades without visiting their family and hometown, increasing the yearn (boredom) to each other, family and hometown. Years in exile were flying and together with them the visits to Kosovo reduced. Visits and contacts with the country of origin has been reduced, and it is mostly expressed to the new generations who are educated in the host country, they have created the social cycle, obligations at work, school, creation of family and other factors who over the time makes that the interest on visiting the country of the origin be reduced. About $40 \%$ of emigrants visit their country of origin only once a year, others 2 times and more (Gollopeni, 2015).

For emigrants who have emigrated without family, has been expressed the lack of parental care for their children, for which numerous sociological studies (Islami, 1985) have shown that children without parental care or one parent are associated with low success on lessons and deviated behaviour same like in Kosovo. Effects of emigration are presented in the delay of marriages or late marriages, reduction of the birth rate, the number of divorces increase etc. Based on studies conducted in Kosovo, the cause of 13\% of divorced couples is emigration (Gollopeni, 2010). Many young boys and girls have been married with foreign citizens and Albanian emigrants with regulated status in the host country, which relation is done, not by the sense of love for each other, but more for the interest to regulate the documentation (residence and work permits) to the host country. Some of these marriages had been short-lived marriage and as a result of these marriages, is increased the number of divorces in Kosovar society, which phenomenon was not known at this stage by the Kosovar society before the 90s (Gollopeni, 2010).

From many years of employment abroad, serious consequences are undoubtedly the health and reduction of working capacity. Since the worker of the immigrant country refuses the hard works such as black metallurgy, other heavy industries, construction, etc., the foreign worker, especially the unqualified one, were obliged to accept those jobs that are offered; they go there unskilled and uneducated, as is the case with the emigrants of Kosovo, or will be re-qualified for heavy works (Islami, 1985). Also, the employment with long time (over the norm), difficult housing 
conditions and malnutrition (particularly this situation is about those who emigrated before 2000), made that the medical condition of Kosovar migrants to be deteriorated. Such a situation clearly shows the large number of Kosovar retired prematurely abroad as a result of the bad state of health.

\section{Some of the main benefits the emigration brought to the country of the ori-}

gin - regarding the emigration should never be seen only the negative sides or losses but also the positive sides. The positive aspects of emigration are multidimensional, so it is difficult to research from a single narrow scientific field. The emigration of Kosovar society had an important role in the processes through which Kosovo has passed. Due to the support from Diaspora it was enabled the survival of families and our society in general. The early 90s finds Kosovo on a very critical social - economic and political situation, and it is the Diaspora who helped with money, clothes, food and other forms of support, without which would be difficult imaginable the survival of Kosovo Albanians. The Diaspora has helped Kosovar families during the 70 s and 80 s to build their houses, purchase the electronic devices, has helped financially the parallel system of education and health (90s) which was established by Kosovar society to help the population on health and education, has helped financially the last war in Kosovo ('98 - '99) for the liberation of Kosovo, organizing protests in major European and American centres, establishing friendship with these countries and other forms, Diaspora helped to raise the unresolved issue of Albanians, the status of Kosovo. Among others the Kosovar Diaspora has made a major contribution in sensitizing the international community towards political and economic situation in Kosovo.

The contribution of Kosovar Diaspora has been great even after the liberation (99) and independence of Kosovo (2008). It was Diaspora which after the war in Kosovo (99) and widespread destruction occurred, helped the households and Kosovar entrepreneurs, with money, bringing innovative technology and other forms for reconstruction and construction of houses, on the revival of the economy of the country and creation of new jobs. The remittances from Diaspora represent one of the main sources of household consumption and represent a source that provides a stable social situation by reducing the burden on the state budget (CBK, 2013). According to a study done by the Kosovo Agency of Statistics and the United Nations Development Program (UNDP) in 2012, the total amount of remittances sent is estimated to be 457 million Euros, or otherwise 9.3\% of Gross Domestic Product in Kosovo (KAS and UNDP, 2013). According to this study, 22.4\% of Kosovo households received remittances. In 2012 food consumption have gotten $36 \%$ of the budget of Kosovo economies receiving remittances in goods and services, half of these deliveries are clothing (49\%) followed by deliveries for cars (20\%), purchase of land (11\%), and household furniture (8\%). Thus, during the last three months of 2012 remittances from Germany constitute approximately 34\% of total remittances received in Kosovo, from Switzerland around 21\%, Italy 9\%, Austria 6\%, US over $4 \%$ (CBK 2013). Kosovar Diaspora gave a valuable contribution to the education of young people in Kosovo and abroad, as well as health needs, in curing many Kosovar citizens in important international centres. Also, it gave a financial contribution on building national institutions, the continued support for families in need (poor 
families). Kosovar society had a low level of education and, in this regard, Diaspora contributed by bringing common experiences from developed countries and bringing common techniques and technology, thus making the Kosovar society to make rapid progress. Kosovar Diaspora continues to be a national capital for the stability of Kosovo in general.

\section{Conclusions}

The hard socioeconomic and political situation during the second half of the XX century in Kosovo has make many citizens to leave the country and look for a job outside of Kosovo, which would ensure a better living of their families left in Kosovo. The migrants were mainly young males and keeper of families while in Kosovo remaining; women, the elderly and children without a parent. Systematic persecution by the Serbian regime, have made many citizens (Kosovo Albanian), in particular Kosovar intellectuals to leave the country for years to come. This difficult situation for Kosovar society culminated in 1999 when, under heavy artillery used by military and police, Serbia expelled from Kosovo around 850000 Kosovar Albanian citizens. The social and political cause (war) of that time (99), makes the international community to intervene militarily to prevent the mass exodus of Kosovo and bringing the normality. So, it became possible the return back of Kosovo citizens. In this way, for citizens were created the hopes for a better life, but this did not last long. Destructions in family and social economies happened during the war, made the Kosovar society to invest all their individual savings in the construction and reconstruction of houses, but the international community invested as well. Although there were major investments by the international community in all the spheres of social life, they were insufficient for a dignified life.

After 2000, the Kosovo's budget was too small to provide a better life for citizens, on the other hand, it was the high level of organized crime, corruption, unemployment, poverty and nepotism which slowly overthrown the hope of Kosovar citizens that in Kosovo could be any perspective, making many Kosovars who were already return to Kosovo to re-emigrate again and those who emigrated without families, to emigrate with their families. In 2014/15, the Kosovar migration to European countries was on a large scale, resembled the 90s and Middle Eastern countries (2015), where openly and so perfectly organized, every evening from the major centres of Kosovo (Pristina, Ferizaj, etc.) many buses with Kosovars emigrated to European countries. The emigration of Kosovo became a topic of discussion in around and world media. The most vital structures of society such as men, women and children migrated. Many children left schools and many families sold their real estate (house, land, cars etc.) they had in Kosovo, to provide money for emigration to European countries. Although there is no a proper census of Kosovar Diaspora, and the statistics that provide various institutions in Kosovo, sometimes have manipulative purposes, however, the most reliable ones show us that around $30 \%$ of the total population of Kosovo lives abroad. If we had any real record of the Kosovar Diaspora, these figures would be even higher. While the main reasons of emigration were the high level of unemployment, poverty, corruption and organized crime, the loss of hope 
for a developing perspective of the country, reunion with the family and relatives and other reasons.

Emigration had a negative effect on the changing of the population structures. It is increased the third age population up to $7 \%$, the changes are emphases also on the age and sex, reducing the number of births, delay marriages, increasing divorces, departure of the workforce, low success in school for children without one parent, separation from other family members and others. However, there were positive aspects of emigration for the country of the origin (Kosovo). Kosovar emigration played an important role in keeping alive the Kosovar society and its institutions through remittances, food, clothes, capital investments, investments in education and health, bringing advanced techniques and technologies, innovation, internationalization of the unresolved status of Kosovo and other aspects. Diaspora constitutes an important asset for Kosovo's economic capital and enables maintaining stable economic situation in the country.

Considering the importance of relationships and communication with Diaspora, in 2011 the Government of the Republic of Kosovo has established the Ministry of Diaspora, as the successor of the Diaspora Agency, which operated within the Office of the Prime Minister of Kosovo. This ministry has developed policies for inclusion of Diaspora in political and social life in the country, also the promotion and preservation of Albanian language, tradition and culture etc.., but there is still more work to be done in implementation. Firstly, it is needed to be done the registration of Kosovar emigrants, organizing additional classes in Albanian and other cultural activities in host countries, establishment of appropriate policies to attract Diaspora to invest in Kosovo, involvement of Diaspora in the public life of Kosovo, establishing the municipal offices for Diaspora which will serve as a bridge between the Diaspora in the country of the origin and vice versa. If the Kosovo institutions do not take these following actions, in a near future, it is likely that, as a result of the difficult social and economic situation in Kosovo, and, with the liberalization of visas for Kosovars, new wave of international migration in Kosovo will occur spatially for young and qualified "brain drain" people. So, the difficult social and economic situation and liberalization for Kosovo citizens increase the possibility for new wave of emigration from Kosovo.

\section{Bibliography and sources}

1. Artjoms. I. and Roswitha M. K. (2008). Kosovo - winning its independence but losing its people? Recent evidence on emigration intentions and preparedness to migrate.

2. Baletic, Z. (1982). International Migration in Modern Economic Development. With special Reference to Yugoslavia. International Migration Review, 6 (4): 736-756.

3. Behrami, S. (2013). Disertacioni: "Population and settlements of the northern region of Kosovo". Tirana.

4. Blaku, R. (1996). The exodus of Albanians and repatriation. Prishtina: QIK. 
5. Blumi, I. "Defining Social Spaces by Way of Deletion: the Untold Story of Albanian Migration in the Post-war Period". Journal of Ethnic and Migration Studies, 29-6, 2003 Dade, Carlo (2006). "Policy Considerations for Working with Diaspora Populations", Canadian Foundation for Americas - Focal.

6. CBK, (2013). Analysis on Ways of sending remittances in Kosovo. Prishtina: CBK.

7. Dahinden, J. (2005). Prishtina - Schlieren. Albanische Migrationsnetzwerke im transnationalen Raum. Zürich: Seismo.

8. Gashi, A. and Haxhikadriaj, A. (2012). Social Impact of Emigration and RuralUrban Migration in Central and Eastern Europe. Prishtina.

9. Gollopeni, B. (2010). Causes and consequences of divorce in Kosovo in the period 1950-2007. Acta Lingua Gegraphica Journal, No. 8: 88-104. Skopje: Publishing SAK-STIL.

10. Gollopeni, B. (2010). Demographic evolution in Dragash Municipality - development trends. Journal of Social Studies, vol. No. 7: 89-98. Tirana: AIS.

11. Gollopeni, B. (2015). Doctoral Thesis: External migration in Kosovo: Study case in Subareka. Skopje: University of Ss Cirili and Metodi.

12. Halpern, Joel M. (1975). Some Perspectives on Balkan Migration Patterns (with Particular Reference to Yugoslavia), in: Tax, S. (Ed.). Migration and Urbanization. Models and Adptive Strategies. The Hague: Monton Publishers, p. 77-115.

13. Halpern, Joel M. (1987). Yugoslav Migration Process and Employment in Western Europe: A Historical Perspective, in: Buechler, H. Christian and Judith-Maria Buechler (Eds.). Migrants in Europe: the Role of Family, Labor, and Politics. Connecticut: Greenwood Press, Inc., p. 91-116.

14. Haxhikadrija, A. (2009). Diaspora as a driving force for development in Kosovo: Myth or reality? Prishtina.

15. Islami, H. (1985). Kosovo village sociologic - demographic contribution to the study rural evolution. Prishtina: Rilindja.

16. Islami, H. (2012). Ethnic aspect of migration, Albanians in violent migration flows. Prishtina: ASHAK.

17. KAS (2011). Demographic, social and reproductive health survey in Kosovo, KAS. Prishtina.

18. KAS (2014). Statistical Yearbook of the Republic of Kosovo in 2014. Prishtina: KAS.

19. Malacic, J. (1996). Arbeitsmigration aus Ex-Jugoslawien, in: Fassmann, H. et al. (Hrsg.) (Ed.). Migration in Europa. Historische Entwicklung, aktuelle Trends, politische Reaktionen. Frankfurt: Campus, p. 231-245.

20. Malcolm, N. (1999). Kosovo. A short History. New York: Harper.

21. MD (2013). Strategy for Kosovo Diaspora for 2013-2018. Prishtina: MD.

22. Mesic, M. (1992). External Migration in the Context of the Post-War Development of Yugoslavia, in Allcock, John B., John J. Horton and Marko Milivojevic (Eds). Yugoslavia in Transition. New York/Oxford: Berg, p. 171-198.

23. Obradovic, M. (2005). Colonization and Agrarian Reform in Kosovo 1918-1941. Prishtina: Institute of History.

24. Osmani, J. (2000). Kosovo Serb colonization. Prishtina: ERA.

25. Riinvest (2007). Diaspora and migration policy. Prishtina: Forum 2015.

26. World Bank (2008). Migration and Remittances Factbook. Albania. 
Pregledni rad

\section{Besim Gollopeni}

Sveučilište Mitrovica "Isa Boletini", Priština, Republika Kosovo

e-mail: besim.gollopeni@gmail.com

\section{Iseljavanje s Kosova: uzroci, šteta i korist}

\section{Sažetak}

Povijesno gledano, migracije stanovništva su integralni dio svakog društva. Ekonomski slabo razvijene zemlje poput Kosova su zemlje iz kojih se odlazi. Zemlje jakih ekonomija te društvene i političke stabilnosti su zemlje u koje se odlazi. U prvoj polovini 20. stoljeća s Kosova je uglavnom odlazilo muško stanovništvo u potrazi za poslom i to u pravcu velikih industrijskih centara bivše Jugoslavije (individualna migracija). Nakon sedamdesetih godina prošlog stoljeća emigracija se proširila na europske zemlje. Glavni uzroci iseljavanja s Kosova ležali su u nepovoljnoj ekonomskoj i političkoj situaciji. Prema podacima popisa stanovništva iz 2011. oko 30\% ukupnog stanovništva Kosova živi u inozemstvu. Novčane pošiljke emigranata igraju važnu ulogu u razvoju Kosova. Postoje, međutim, i negativni aspekti emigracije kao što su gubitak mladog stanovništva, gubitak obrazovanog stanovništva, rodni i dobni disbalans u zemlji porijekla itd.

Analizom statističkih podataka i raznih studija, koristeći analitičke, povijesne, komparativne i demografske metode, ovaj rad proučava vremenske periode i socio-demografske karakteristike emigracije, iseljavanje po općinama na Kosovu, odredišta, motive, štetu i dobrobit emigracije.

Ključne riječi: migracija, društvo/zemlja domaćin, motivi, šteta, korist. 